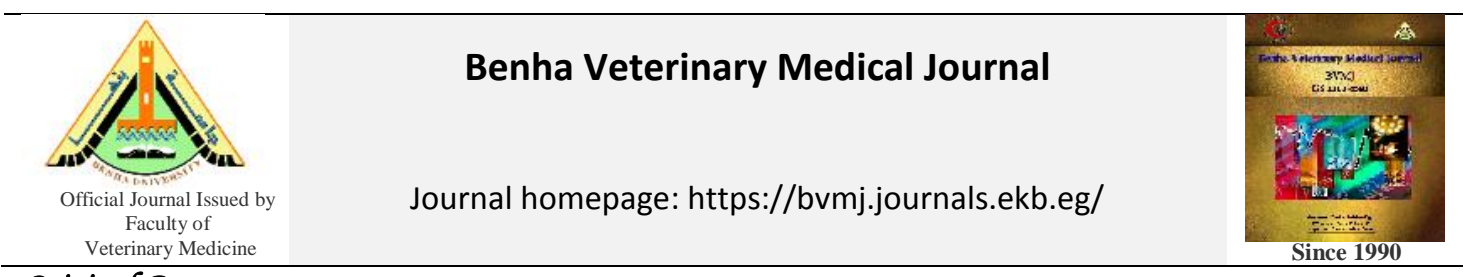

Original Paper

\title{
Incidence of Psychotropic bacteria in frozen chicken meat products with special reference to Pseudomonas species
}

Mohamed A. Hassan', Hemmat M. Ibrahim', Nahla A. Shawky², Suzan H. Sheir ${ }^{2}$

${ }^{I}$ Department of Food Hygiene, Faculty of Veterinary Medicine, Benha University

${ }^{2}$ Animal Health Research Institute, Shebin El-Koom Branch

\section{ARTICLE INFO}

\begin{tabular}{l}
\hline Keywords \\
frozen chicken meat \\
products \\
Pseudomonas species. \\
Psychotropic bacteria
\end{tabular}

Received 10/08/2020

Accepted 04/09/2020

Available On-Line

$01 / 10 / 2020$

\begin{abstract}
Total of hundred random samples of frozen chicken products represented by breast, thigh, nuggets and burger (25 of each) were collected from various supermarkets located in Menoufia government. To study the incidence of psychotropic bacteria with special reference to Pseudomonas species. The study revealed that mean values of Psychotropic count were $8.17 \times 10^{3} \pm 1.42 \times 10^{3}, 1.95 \times 10^{4} \pm 2.06 \times 10^{4}, 3.63 \times 10^{4} \pm 0.89 \times 10^{4}$ and $7.58 \times 10^{4} \pm 1.16 \times 10^{4}$ respectively while the mean value of Pseudomonas counts were $3.51 \times 10^{3} \pm 0.76 \times 10^{3}$, $6.29 \times 10^{3} \pm 1.12 \times 10^{3}, 8.44 \times 10^{3} \pm 1.85 \times 10^{3}, 1.71 \times 10^{4} \pm 0.36 \times 10^{4}$ respectively for examined frozen breast, thigh, nuggets and burger. It was obvious that 166 isolates were identified as $P$. acidovorans, $P$. aeruginosa, $P$. alcaligenes, $P$. cepacia, $P$. fluorescens, $P$. fragi, $P$. proteolytica, $P$. putida, $P$. putrefaciens, $P$. stutzeri, $P$. vesicularis. The prevalence of Pseudomonas were $6,1,33,8,47,10,19,3,22,2$ and 15 from examined samples, respectively, where the highest contaminated product was the chicken burger 54/166 (32.5\%) Pseudomonas isolates and Ps. Fluorescens was the most detected isolate. The isolation of Pseudomonas species from food samples is highly significant Therefore, its presence should be prevented during earlier stages of food preparation.
\end{abstract}

\section{INTRODUCTION}

Chicken meat is considered a highly nutritive food with a relatively cheap price and low fat and cholesterol content, consumed worldwide. However, it is highly perishable, and its storage life is relatively short even refrigerated temperature (Mantilla et al., 2011). Chicken meat has a short shelf life because psychrotrophic bacteria causes spoilage or off-flavors even at cold storage conditions (Carrizosa et al., 2017). The spoilage of meat depends on $\mathrm{pH}$ level, availability of oxygen, biodiversity of bacterial groups, and storage temperature (Ercolini et al., 2010). These factors, in turn, are closely associated with the growth of spoilage bacteria. The abuse of temperature control and poor food handling could encourage the growth of microorganisms which leads to contamination and spoilage of food (Gour et al., 2014). Storage temperature, however, is the most important factor that affects the growth of bacteria present in chicken meat. Psychrotrophic bacteria can grow at refrigerated conditions, and temperature can affect various microbial growth parameters including maximum growth rate and total bacterial counts (Mataragas et al., 2006). Pseudomonas spp. is a major psychrotrophic bacterium that produces proteinase and its optimal $\mathrm{pH}$ is from 6.5 to 8.0. proteinase hydrolyses chicken protein and cause spoilage (Nowak et al., 2012). Pseudomonas spp. found everywhere and are isolated from a different of sources like drinking water, human beings, plants, and also from a diversity of foods.
Pseudomonas is an aerobic, Gram-negative bacterium that is commonly found in soil. It can grow well in a range of temperature levels, from 2 to $35^{\circ} \mathrm{C}$ (Ercolini et al., 2010), and can be easily found in chilled food products, as well as food prepared at room temperature. In the food industry, various foods harbor very diverse Pseudomonas species. Most of the isolates have the ability to grow at a low temperature and are capable of secreting enzymes that can affect the overall quality of the food products including cold-stored food (Caldera et al., 2016).

Four species of Pseudomonas, namely, P. fluorescens, $P$. lundensis, $P$. fragi, and $P$. viridiflava, are the main cause of food spoilage because these organisms produce enzymes and form a biofilm, thus causing spoilage in refrigerated food (Rawat 2018). For instance, P. fluorescens has been associated with spoilage of chicken carcasses. When its population reaches $10^{8} \mathrm{cfu} / \mathrm{ml}$, it could cause the production of a strong foul smell (Wang et al., 2014). In addition, $P$. fragi is commonly known to spoil milk and meat (Ercolini et al., 2010). This could also lead to the production of odor and slime in food products. Reusing the ingredients stored at room temperature for few hours pose risk to consumers especially if they are immune compromised (Tsao et al., 2018). Apart from being a spoilage microorganism, Pseudomonas spp. could cause urinary and blood stream infection. This is due to the fact that they develop resistance to certain antibiotics (Golemi-Kotra et al., 2008). Pseudomonas species decreases the storage life of food products and consequently their quality by producing enzymes as proteolytic and lipolytic which are the primary

* Corresponding author:, Suzan H. Sheir, Animal Health Research Institute, Shebin El-Koom Branch 
reason of food spoilage during storage (Franzetti and Scarpellini, 2007).

Therefore, the current study was carried out to evaluate the incidence of Psychrotrophic bacteria with especial reference to Pseudomonas species.

\section{MATERIAL AND METHODS}

\subsection{Collection of samples:}

A total of 100 random samples of frozen chicken products (each weighting $250 \mathrm{gm}$ ) represented by breast, thigh, nuggets and burger (25 of each) were collected from different supermarkets located in Menoufia government at different periods of time. Each sample was kept individually in separate plastic bag and was taken directly to the laboratory in an insulated ice box under complete aseptic conditions without undue delay.

The collected samples were examined bacteriologically for determination of their contamination with psychrotrophic and Pseudomonas bacteria.

\subsection{Preparation of samples (FDA, 2002):}

Under complete aseptic conditions, 25grams of the sample were weighed and transferred into a sterile flask containing $225 \mathrm{ml}$ of sterile peptone water $(0.1 \%)$. The content of the flask was homogenized for 3 minutes at $14000 \mathrm{rpm}$ then allowed to stand for 5 minutes at room temperature. One $\mathrm{ml}$ from the homogenate was transferred into a separate tube containing $9 \mathrm{ml}$ of sterile peptone water $(0.1 \%)$ from which tenfold serial dilutions was prepared. The prepared samples were subjected to the following examinations:

2.2.1. Determination of Psychrotrophic count (ISO, 2002)

2.2.2 Determination of Pseudomonas count (ISO, 2004)

Accurately, $0.1 \mathrm{ml}$ of each sample homogenate was separately inoculated into duplicate Petri-dishes of Pseudomonas selective agar medium base (HiMedia) supplemented with glycerol and evenly spread. The inoculated plates were incubated at $25^{\circ} \mathrm{C}$ for 48 hours after which all developed colonies (greenish yellow colonies) were enumerated. The average count was calculated and recorded.

\subsubsection{Identification of isolated Pseudomonas species:}

The suspected colonies were purified and subcultured on nutrient agar slopes and incubated at $37^{\circ} \mathrm{C}$ for 24 hours. The purified colonies were subjected for further identification including morphological and biological identification according to Macfaddin (2000).

\subsection{Statistical Analysis:}

All the obtained results were statistically analyzed using the analysis of variance (ANOVA test) according to Feldman et al. (2003).

\section{RESULTS}

\subsection{Psychrotrophic count}

The psychrotrophic count in examined samples of chicken meat products was recorded in table (1) and it was ranging from $2.9 \times 10^{3}$ to $3.1 \times 10^{4}, 5.4 \times 10^{3}$ to $7.7 \times 10^{4}, 9.0 \times 10^{3}$ to $1.2 \times 10^{5}$ and $1.1 \times 10^{4}$ to $4.6 \times 10^{5}$ with mean values of $8.17 \times 10^{3} \pm 1.42 \times 10^{3}, 1.95 \times 10^{4} \pm 2.06 \times 10^{4}, 3.63 \times 10^{4} \pm$ $0.89 \times 10^{4}$ and $7.58 \times 10^{4} \pm 1.16 \times 10^{4}$ respectively for the examined frozen breast, thigh nuggets and burger.
Table (1) Statistical analytical results of psychrotrophic counts in the examined samples of chicken meat products $(\mathrm{n}=25)$.

\begin{tabular}{|c|c|c|c|}
\hline Chicken meat products & Min & Max & Mean \pm S.E $E^{*}$ \\
\hline Breast & $2.9 \times 10^{3}$ & $3.1 \times 10^{4}$ & $8.17 \times 10^{3} \pm 1.42 \times 10^{3}$ \\
\hline Thigh & $5.4 \times 10^{3}$ & $7.7 \times 10^{4}$ & $1.95 \times 10^{4} \pm 2.06 \times 10^{4}$ \\
\hline Nuggets & $9.0 \times 10^{3}$ & $1.2 \times 10^{5}$ & $3.63 \times 10^{4} \pm 0.89 \times 10^{4}$ \\
\hline Burger & $1.1 \times 10^{4}$ & $4.6 \times 10^{5}$ & $7.58 \times 10^{4} \pm 1.16 \times 10^{4}$ \\
\hline
\end{tabular}

$\mathrm{SEE}^{*}=$ standard error of mean

\subsection{Pseudomonas counts}

The results showed in table (2) manifested that the Pseudomonas counts (CFU/g) in the examined samples were varied from $1.0 \times 10^{2}$ to $9.3 \times 10^{3}$ with mean value of $3.51 \times 10^{3} \pm 0.76 \times 10^{3}$ for breast, $3.0 \times 10^{2}$ to $2.5 \times 10^{4}$ with mean value of $6.29 \times 10^{3} \pm 1.12 \times 10^{3}$ for thigh, $4.0 \times 10^{2}$ to $3.2 \times 10^{4}$ with mean value of $8.44 \times 10^{3} \pm 1.85 \times 10^{3}$ for nuggets and $4.0 \times 10^{2}$ to $6.1 \times 10^{4}$ with mean value of $1.71 \times 10^{4} \pm 0.36 \times 10^{4}$ for burger.

Table (2) Statistical analytical results of Pseudomonas counts in the examined samples of chicken meat products $(\mathrm{n}=25)$.

\begin{tabular}{lccc}
\hline Chicken meat products & Min & Max & Mean \pm S.E \\
\hline Breast & $1.0 \times 10^{2}$ & $9.3 \times 10^{3}$ & $3.51 \times 10^{3} \pm 0.76 \times 10^{3}$ \\
Thigh & $3.0 \times 10^{2}$ & $2.5 \times 10^{4}$ & $6.29 \times 10^{3} \pm 1.12 \times 10^{3}$ \\
Nuggets & $4.0 \times 10^{2}$ & $3.2 \times 10^{4}$ & $8.44 \times 10^{3} \pm 1.85 \times 10^{3}$ \\
Burger & $4.0 \times 10^{2}$ & $6.1 \times 10^{4}$ & $1.71 \times 10^{4} \pm 0.36 \times 10^{4}$ \\
\hline S.E $^{*}=$ standard error of mean & & &
\end{tabular}

\subsection{Incidence of identified Pseudomonas species.}

The identified species of Pseudomonas isolated from the examined samples of frozen chicken products was recorded in table (3) and its incidence rate showed that Ps. alcaligenes, $P$. cepacia, $P$. fluorescens, $P$. fragi, $P$. proteolytica, $P$. putrefaciens, $P$. vesicularis. were isolated from 4(16\%), 1(4), 9(36\%), 2(8\%), 5(20\%), 4(16\%) and $2(8 \%)$. The examined samples of chicken breast, $P$. acidovorans, $P$. alcaligenes, $P$. cepacia, $P$. fluorescens, $P$. fragi, $P$. proteolytica, $P$. putida, $P$. putrefaciens, $P$. vesicularis were isolated from 1(4\%), 7(28\%), 2(8\%), $11(44 \%), 4(16 \%), 3(12 \%), 1(4 \%), 7(28 \%)$ and $3(12 \%)$ from the examined samples of chicken thigh.

Table (3) Incidence of identified Pseudomonas species isolated from the examined samples of chicken meat products $(\mathrm{n}=25)$.

\begin{tabular}{|c|c|c|c|c|c|c|c|c|}
\hline \multirow{3}{*}{$\begin{array}{l}\text { Pseudomonas } \\
\text { spp. }\end{array}$} & \multicolumn{8}{|c|}{ Chicken meat products } \\
\hline & \multicolumn{2}{|c|}{ Breast } & \multicolumn{2}{|c|}{ Thigh } & \multicolumn{2}{|c|}{ Nuggets } & \multicolumn{2}{|c|}{ Burger } \\
\hline & No & $\%$ & No & $\%$ & No & $\%$ & No & $\%$ \\
\hline P. acidovorans & 0 & 0 & 1 & 4 & 3 & 12 & 2 & 8 \\
\hline P. aeruginosa & 0 & 0 & 0 & 0 & 0 & 0 & 1 & 4 \\
\hline P. alcaligenes & 4 & 16 & 7 & 28 & 10 & 40 & 12 & 48 \\
\hline P. cepacia & 1 & 4 & 2 & 8 & 2 & 8 & 3 & 12 \\
\hline P. fluorescens & 9 & 36 & 11 & 44 & 12 & 48 & 15 & 60 \\
\hline P. fragi & 2 & 8 & 4 & 16 & 1 & 4 & 3 & 12 \\
\hline P. proteolytica & 5 & 20 & 3 & 12 & 5 & 20 & 6 & 24 \\
\hline P. putida & 0 & 0 & 1 & 4 & 2 & 8 & 0 & 0 \\
\hline P. putrefaciens & 4 & 16 & 7 & 28 & 3 & 12 & 8 & 32 \\
\hline P. stutzeri & 0 & 0 & 0 & 0 & 1 & 4 & 1 & 4 \\
\hline P. vesicularis & 2 & 8 & 3 & 12 & 6 & 24 & 4 & 16 \\
\hline
\end{tabular}

Whereas $P$. acidovorans, $P$. alcaligenes, $P$. cepacia, $P$. fluorescens, $P$. fragi, $P$. proteolytica, $P$. vesicularis, $P$. putrefaciens, $P$. stutzeri, $P$. putida were isolated from 3 (12\%), $10(40 \%), 2(8 \%), 12(48 \%), 1(4 \%), 5(20 \%), 2$ $(8 \%), 3(12 \%), 1(4 \%)$ and $6(24 \%)$ from the examined 
samples of chicken nuggets and $P$. acidovorans, $P$. aeruginosa, $P$. alcaligenes, $P$. cepacia, $P$. fluorescens, $P$. fragi, $P$. proteolytica, $P$. vesicularis, $P$. stutzeri, $P$. putrefaciens were isolated from $2(8 \%), 1(4 \%), 12(48 \%)$, $3(12 \%), 15(60 \%), 3(12 \%), 6(24 \%), 8(32 \%), 1(4 \%)$ and $4(16 \%)$ from the examined samples of chicken burger.

\section{DISCUSSION}

The psychrotrophic counts have been always used as a general indicator of the potential shelf life of chicken (Capita et al., 2001). It is distinct from the results which demonstrated in table (1) that higher psychrotrophic counts were recorded by Morshdy et al. (2018). $2.8 \times 10^{4} \pm 1.1$ $\times 10^{4}$ in frozen pane, Hassanien et al. (2016). $5.71 \times 10^{6} \pm$ $1.44 \times 10^{6}$ and $4.59 \times 10^{6} \pm 1.26 \times 10^{6}$ in frozen breast and thigh, Azab (2016). recorded that psychrotrophic count was $9.2 \times 10^{6} \pm 12.49 \times 10^{6}$ and $8.5 \times 10^{6} \pm 14.61 \times 10^{6}$ in breast and thigh and Abd EL-Magied et al. (2009). Found that the psychrotrophic count was $1.43 \times 10^{5} \pm 0.37 \times 10^{5} / \mathrm{g}$ in breast samples and $4.28 \times 10^{6} \pm 0.38 \times 10^{6} / \mathrm{g}$ in wings.

Relatively the same psychrotrophic count were recorded by Eid et al (2014). $11.5 \times 10^{3} \pm 2.2 \times 10^{3}$ in chicken breast and Elkewaiey (2012). was $8.6 \times 10^{4} \pm 1.5 \times 10^{4}$ in chicken nuggets comparatively with Morshdy et al. (2018) who recorded lower results of psychrotrophic count which was $1.9 \times 10^{3} \pm 0.9 \times 10^{3}$ in chicken nuggets. And Dan et al. (2008). Who recorded that the mean value was $2.88 \pm 0.32$ $(\log 10) \mathrm{cfu} / \mathrm{g}$. The contamination of chicken meat products with great number of psychrotrophic bacteria could be attributed to the neglected sanitary measures adapted during intensive preparation, processing, handling and packaging as well as cold storage. (Cenci et al. 1990).

The findings recorded in table (2) coincide with other studies that recorded relatively the same count of Pseudomonas species in chicken products that were 3.6

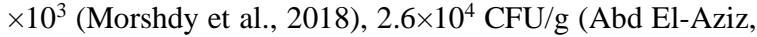
2015), 2.7-3.8 (Bruckner et al., 2012) and $3.6 \mathrm{log}$ cfu/g (Abu-ruwaida et al., 1994).

Hinton et al. (2007) stated that although psychrotrophs weren't isolated from broiler carcasses juts after washing with chlorinated water, Pseudomonas spices was the most prevalent isolated psychrotrophs from all carcasses refrigerated for 7 to 14 days. Pseudomonas spices are found everywhere and isolated from several sources like drinking water, plants, and human beings and also from a variety of foods. To achieve ideal storage life and sensory properties, the initial count of Pseudomonas species shouldn't exceed $100 \mathrm{cfu} / \mathrm{g}$ on chicken products under aerobic conditions (Mead, 2005). Scalding step of poultry can destroy Pseudomonas, but the subsequent processing steps may re-contaminate the product. Many studies indicated that the initial count of Pseudomonas is connecting directly with the storage life of the product at refrigeration temperatures and when the number of pseudomonas organism ranging from $10^{7}$ to $10^{8} \mathrm{cfu} / \mathrm{g}$ in food spoilage will occurs.

It was obvious from results recorded in table (3) that 166 Pseudomonas isolates were identified as $P$. acidovorans, $P$. aeruginosa, $P$. alcaligenes, $P$. cepacia, $P$. fluorescens, $P$. fragi, $P$. proteolytica, $P$. putida, $P$. putrefaciens, $P$. stutzeri, $P$. vesicularis with an incidence of $6,1,33,8,47,10,19$, $3,22,2$ and 15 from examined samples, respectively. The highest contaminated product was the chicken burger $56 / 166(32.5 \%)$ of Pseudomonas isolates and Ps. fluorescens, was the most detected isolate. From this results, burger samples were recorded the highest contaminated product with psychrotrophic and Pseudomonas species which may be due to malpractices, excessive handling, poor hygienic quality of raw materials especially the added spices and unhygienic practices during production and storage.

Arnaut-Rollier et al. (1999) in a study on fresh and refrigerated chicken skin, reported the prevalence of 4 main Pseudomonas spp. including Pseudomonas fragi, Pseudomonas lundensis, Pseudomonas fluorescens biovars and an unidentified strain similar to $P$. fluorescens biovars, 16 different species of Pseudomonas were isolated from 12 samples of chicken meat and Pseudomonas weihenstephanensis and Pseudomonas psychrophila were the most abundant lee et al. (2017) and 11 isolates of Pseudomonas were isolated from uncooked chicken burger and were identified as P.fragi 8, P. fluorescens 1 and $P$. chicorii 2 Franzetti and Scarpellini (2007).

In contrast no $P$. aeruginosa were isolated from any of hundred chicken meat samples examined by Iroha et al. (2011).

Food spoilage is usually associated with $P$. fluorescens, $P$. aeruginosa, $P$. fragi, and $P$. lundensis. (Caldera et al., 2016) in addition to this, the ability of these spoilage bacteria to survive under refrigeration temperatures may cause difficulty during the storage of foods. (Bellés et al. 2017; Wang et al., 2017).

Presence of Pseudomonas spp. in food samples is of great significance as the organism is considered as a pathogenic bacterium for man and as an indicator of food quality, Yagoub (2009). Apart from being a spoilage microorganism, Pseudomonas spp. could cause urinary and blood stream infection, Golemi-Kotra (2008).

\section{CONCULSION}

The presence of these opportunistic bacteria should be prevented during earlier stages of food preparation. Additionally, during serving, temperature abuse will lead to spoilage of food leading to bad odor and taste, which is not palatable for customers that can affect sales and reputation of the food service establishments.

\section{REFERENCES}

1. Abd El-Aziz, D.M., 2015. Detection of Pseudomonas spp. in Chicken and Fish Sold in Markets of Assiut City, Egypt. Journal of Food Quality and Hazards Control 2: 86-89.

2. Abd EL-Magied-Walaa, K.A., Hassan, M.A., Shaltout, F.A., Lamada- Hanan, M., 2009. Occurrence of psychrotrophic pathogens in chicken meat products. M. V. Sci. (Meat hygiene) Thesis, Fac. Vet. Med., Benha University.

3. Abu-Ruwaida, A. S., Sawaya, W.N., Dashti, B.H., Baroon, Z.H., AL-Othiman, H.A., 1996 Microbiological shelf life and quality of frozen broiler chicken under stimulated market temperatures. Fleischwirschaff . 76: 827-830.

4. Arnaut-Rollier, I. Vauterin, L. DeVos, P. Massart, D.L. Devriese, L.A. De-Zutter, L., Van-Hoof, J., 1999. A numerical taxonom-ic study of the Pseudomonas flora isolated from poultry meat. J. Applied Microbiology. 87: 1528.

5. Azab-Amira, M.A., 2016. Effect of Freezing on Chicken Meat Quality. M. V. Sc. Thesis (Meat Hygiene). Fac. Vet. Med, Zag. Univ., Egypt.

6. Bellés, M., Alonso, V., Roncalés, P., et al. 2017. A review of fresh lamb chilling and preservation. Small Ruminant Research.146:41-7. 
7. Bruckner, S., Albrecht, A., Petersen, B., Kreyenschmidt, J., 2012. Influence of cold chain interruptions on the shelf life of fresh pork and poultry. International Journal of Food Science \& Technology 47, 1639-1646.

8. Caldera, L., Franzetti, L., Van-Coillie, E., et al. 2016. Identification, enzymatic spoilage characterization and proteolytic activity quantification of Pseudomonas spp. isolated from different foods. Food Microbiology 54:142-53.

9. Capita, R., Alonso, C.C., Delcamino, M.G.A., Moreno, B., 2001. Microbiological Quality of Retail Poultry Carcasses in Spain. Journal of Food Protection, 64(12): 1961-1966.

10. Carrizosa, E., Benito, M.J., Ruiz-Moyano, S., Hernández, A., Villalobos, M.D.C., Martín, A., Córdoba, M.D.G., 2017. Bacterial communities of fresh goat meat packaged in modified atmosphere. Food Microbiol. 65, 57-63.

11. Cenci, P., Corrodini, L., Vitaioli, M., Rausa, G., 1990. Comparison of the microbiological profile of rural and industrial poultry 1. Enterobacteriacae. Igiene moderna, 94(2):207-211

12. Dan, S.D., Mihaiu, M., Rotaru, O., Ioana, D., 2008 Microbiological hazard evaluation represented by the psychrotrophic grams from the level of avain carcasses. Bulletin USAMV Veterinary Medicine, 65(2) Pissn.18435270; Eissn. 1843-5378.

13. Eid, A.M., Eltalawy, M.F., Zahran, S.E. and Khedre, A. Z. 2014. Bacteriological and chemical evaluation of some heat treated chicken products. Benha Vet. Medical J. 27(2): 437:443.

14. El-Kewaiey, I. A., 2012. Quality assessment of some readyto-eat and locally produced chicken meat products. Assiut Vet. Med. J. 58 (132): 117

15. Ercolini, D., Casaburi , A., Nasi , A., et al. 2010. Different molecular types of Pseudomonas fragi have the same overall behavior as meat spoilers. Int J Food Microbiol., 142(12):120-31.

16. Feldman, D., Ganon, J., Haffman, R., Simpson, J. 2003.The solution for data analysis and presentation graphics. $2^{\text {nd }}$ Ed., Abacus Lancripts, Inc., Berkeley, USA

17. Food and Drug Administration "FDA" 2002. Enumeration of coliform bacteria and identification of E. coli. In Bacteriological Analytical Manual. Center for Food Safety and Applied Nutrition, Department of Health and Human Searches $8^{\text {th }}$ ed. US FDA, Chapter 4.

18. Franzetti, L., Scarpellini, M., 2007. Characterization of Pseudomonas spp. isolated from foods. Annals of Microbiology 57:39-47.

19. Golemi-Kotra, D., 2008. Pseudomonas Infections. X Pharm. The Comprehensive Pharmacology Reference. Elsevier. 1-8.

20. Gour, S., Khare, M., Patidar, R.K., et al. 2014. Screening of microorganisms from different sites of restaurants and dhabas. IJPSR (1):183-188.

21. Hassanien- Fatin, M., El-Sabagh -Rasha, A., NassiefMarionet, Z., Refat, M.S., 2016. Bacterial and Chemical quality of Frozen Chicken Meat Received at Governmental Hospital modern. Benha Vet. Medical J., 30(1): 109-117.

22. Hinton, A.J.R., 2007. Northcutt J.K., Smith D.P., Musgrove M.T., Ingram K.D. Spoilage microflora of broiler carcasses washed with electrolyzed oxidizing or chlorinated water using an inside-outside bird washer. Poultry Science. 86: 123-127.

23. Iroha, I.R., Ugbo, E.C., Ilang, D.C., Oji, A.E., Ayogu, T.E., 2011. Bacterial contamination of raw meat sold in Abakaliki,
Ebonyi State Nigeria. Journal of Public Health and Epidemiology. 3: 49-53

24. International Standards Organization "ISO" 2002 Horizontal method for enumeration of microorganisms, colony count technique at $30^{\circ} \mathrm{C}$. International Standards Organization, Geneva.

25. International Standards Organization "ISO" 2004. Microbiology of food and animal feeding stuffs. Horizontal method for detection and enumeration of Enterobacteriaceae, Part 2: colony count method. International Standards Organization, Geneva.

26. Laura, F., Mauro, S., 2007. Characterization of Pseudomonas spp. isolated from foods Annals of Microbiology. 57 (1): 39-47.

27. Lee, H.S., Kwon, M., Heo, S., Kim, M.G. and Kim, G. 2017. Characterization of the Biodiversity of the Spoilage Microbiota in Chicken Meat Using Next Generation Sequencing and Culture Dependent Approach. Korean J. Food Sci. An. 37(4): 535-541.

28. Macfaddin , J.F.2000. Biochemical tests of identification of medical bacteria .3rd Ed., Lippincott Williams and Wilkins Washington, Philadelphia . USA

29. Mantilla, S.P.S., Santos, É.B.H., Vital, D.C., Mano, S.B. Freitas, M.Q.D., Franco, R.M., 2011. Microbiology, sensory evaluation and shelf life of irradiated chicken breast fillets stored in air or vacuum. Brazilian Archives of Biology and Technology 54, 569- 576

30. Mataragas, M., Drosinos, E.H., Vaidanis, A., Metaxopoulos, I., 2006. Development of a predictive model for spoilage of cooked cured meat products and its validation under constant and dynamic temperature storage conditions. J. Food Sci. 71, 157-167.

31. Mead, G.C., 2005. Food safety control in the poultry industry. Woodhead Publishing Limited, USA.

32. Morshdy, A.M., Hussein, M.A. and El-Arabay, A.E. 2018 Chemical and Microbial Profile of Some Chicken Products. 5th International Food Safety Conference Damanhour University.

33. Nowak, A., Rygala, A., Oltuszak-Walczak, E., Walczak, P., 2012. The prevalence and some metabolic traits of Brochothrix thermosphacta in meat and meat products packaged in different ways. J. Sci. Food Agric. 92, 13041310.

34. Rawat, S., 2015. Food spoilage: Microorganisms and their prevention. Asian J Plant Sci Res. 5(4): 47-56.

35. Tsao, L-H., Hsin, C-Y., Liu, H-Y., et al. 2018. Risk factor for healthcare-associated infection caused by carbapenem resistant Pseudomonas aeruginosa. J Microbiol, Immunol and Infect 51:359-366.

36. Wang, G., Wang, H., Han, Y., et al. 2017. Evaluation of the spoilage potential of bacteria isolated from chilled chicken in vitro and in situ. Food Microbiol 63:139-46.

37. Wang, J. Zhuang, H. Hinton, A. et al. 2014. Photocatalytic disinfection of spoilage bacteria Pseudomonas fluorescens and Macrococcus caseolyticus by nano-TiO2. LWT - JFST. 59(2): 1009-17.

38. Yagoub, S.O., 2009. Isolation of Enterobacteriaceae and Pseudomonas spp. from raw fish sold in fish market in Khartoum state. Journal of Bacteriology Research. 1: 85-88. 